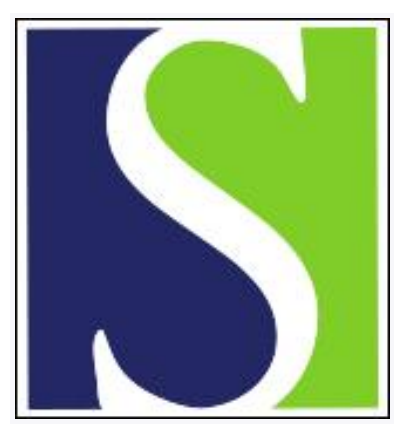

Scand J Work Environ Health 1978;4(4):265-274

https://doi.org/10.5271/sjweh.2699

Issue date: Dec 1978

Clinical features, mortality and survival of patients with asbestosis.

by Huuskonen MS

Key terms: asbestosis; clinical feature; life expectancy; lung cancer; lung cancer; mortality; patient; survival

This article in PubMed: www.ncbi.nlm.nih.gov/pubmed/734387

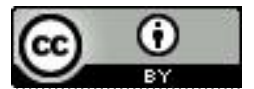




\title{
Clinical features, mortality and survival of patients with asbestosis
}

\author{
by MATTI S. HUUSKONEN, M.D. ${ }^{1}$
}

\begin{abstract}
HUUSKONEN, M. S. Clinical features, mortality and survival of patients with asbestosis. Scand. j. work environ. \& health 4 (1978) 265-274. This paper describes the characteristic clinical features, mortality and survival rate of 202 patients diagnosed as having asbestosis by the Institute of Occupational Health between 1934 and 1976. One hundred and thirty-three patients were subjected to a clinical reexamination. Major findings included breathlessness in $118(88.7 \%)$, persistent sputum in $95(71.4 \%)$, crepitations in $77(58.0 \%)$ and finger clubbing in $43(32.3 \%)$. Of the 95 patients with persistent sputum, $19(20.0 \%)$ were nonsmokers. Of the $174 \mathrm{men}$ registered as having asbestosis, 56 had died, whereas the expected number of deaths among men of the same age in the Finnish general population was only 23.4. The respective figures for lung cancer were 19 observed and 2.1 expected. No excess mortality was found for other malignomas. Among men with asbestosis, the life expectancy was shorter for smokers than for non- and exsmokers.
\end{abstract}

Key words: asbestosis, clinical features, life expectancy, lung cancer, mortality.

Asbestosis-induced disorders can be grouped under the following four headings: (a) diffuse interstitial fibrosis of the lungs (asbestosis), (b) pleural fibrosis and plaque formation, (c) malignant mesothelioma of the pleura or peritoneum, and (d) possible bronchial carcinoma without asbestosis (18). Clinically, asbestosis, the first disorder mentioned, is similar to diffuse interstitial fibrosis with other etiologies (26). Breathlessness on physical effort is the most important early symptom of asbestosis. Often it is even out of proportion to the physical pulmonary signs and radiographic appearances common for asbestosis (18). In the early stages the lung function tests determining lung volume,

1 Department of Occupational Medicine, Institute of Occupational Health, Helsinki, Finland.

Reprint requests to: M. S. Huuskonen, M.D., Institute of Occupational Health, Haartmaninkatu 1, SF-00290 Helsinki 29, Finland. ventilatory capacity and gas transfer may be normal at rest. As fibrosis advances, the changes that occur in lung function correspond to the restrictive syndrome (18). Persistant inspiratory crepitations are also an important sign and may be present before respiratory symptoms or definitive radiographic findings or abnormal lung function at rest is seen (2). According to Parkes (18), finger clubbing is not significantly related to the severity of asbestosis, and it probably does not develop in about one-fourth of all asbestosis patients.

Excess mortality among asbestos workers, especially from lung cancer, has been shown in many earlier studies $(4,14,15$, $16,17,22,23)$. Other types of cancer, such as malignant mesotheliomas of the pleura and peritoneum, laryngeal and ovarial carcinomas, and neoplasias of the gastrointestinal tract, may also be related to asbestos exposure (2). Otherwise, the most severe complications of asbestosis are malignomas, which often occur many decades 
Table 1. Occupation, number, sex, and age at the time of the examination.

\begin{tabular}{|c|c|c|c|c|c|c|c|}
\hline \multirow{2}{*}{$\begin{array}{l}\text { Occupation } \\
\text { and number }\end{array}$} & \multicolumn{2}{|c|}{ Sex } & \multicolumn{5}{|c|}{ Age (years) } \\
\hline & Males & Females & $\leq 39$ & & $40-49$ & $50-59$ & $\geq 60$ \\
\hline $\begin{array}{l}\text { Insulation } \\
\text { workers } \\
\mathrm{N}=55\end{array}$ & 54 & 1 & 1 & mean & $\begin{array}{l}15 \\
55.6\end{array}$ & $\begin{array}{c}19 \\
(34-72)\end{array}$ & 20 \\
\hline $\begin{array}{l}\text { Asbestos } \\
\text { sprayers } \\
\mathrm{N}=8\end{array}$ & 8 & 0 & 5 & mean & $\begin{array}{l}1 \\
41.0\end{array}$ & $(34-54)$ & 0 \\
\hline $\begin{array}{l}\text { Asbestos } \\
\text { cement } \\
\text { product } \\
\text { factory } \\
\text { workers } \\
\mathrm{N}=32\end{array}$ & 16 & 16 & 0 & mean & $\begin{array}{l}2 \\
64.0\end{array}$ & $\begin{array}{c}7 \\
(47-78)\end{array}$ & 23 \\
\hline $\begin{array}{l}\text { Asbestos } \\
\text { quarry } \\
\text { workers } \\
\mathrm{N}=29\end{array}$ & 27 & 2 & 1 & mean & $\begin{array}{l}9 \\
52.9\end{array}$ & $(30-69)$ & 6 \\
\hline $\begin{array}{l}\text { Others } \\
\mathrm{N}=9\end{array}$ & 8 & 1 & 0 & mean & $\begin{array}{l}2 \\
57.3\end{array}$ & $(47 \stackrel{2}{-} 64)$ & 5 \\
\hline $\begin{array}{l}\text { Total } \\
N=133\end{array}$ & 113 & 20 & 7 & mean & $\begin{array}{l}29 \\
56.3\end{array}$ & $\begin{array}{c}43 \\
(30-78)\end{array}$ & 54 \\
\hline
\end{tabular}

after the onset of asbestos exposure (23). In 1949 Merewether (14) reported that $14.7 \%$ of all male patients with asbestosis died of pulmonary neoplasma, but in 1965 Buchanan (4) listed the cancer mortality for male patients at more than $50 \%$.

The aim of the present study was to determine the distribution of clinical features, mortality and survival rates in a series of Finnish patients with asbestosis.

\section{SUBJECTS AND METHODS}

Between 1964 and 1976 a total of 229 cases of asbestosis were reported to the Finnish Register of Occupational Diseases. Of these patients 202 were diagnosed at the Institute of Occupational Health, and they formed the series for the present investigation. One hundred and forty were alive (118 men and 22 women), while 62 had died before the end of 1976 (56 men and 6 women). All the 140 subjects still alive were requested to attend a reexamination; 133 of them responded (113 men and 20 women). These 133 subjects comprised the series for the analysis of clinical features. Data on their occupations and smoking habits are summarized in tables 1, 2 and 3.

In accordance with the usual practice in Finland the following criteria were used for the diagnosis of asbestosis $(27,30)$ : (a) a history of confirmed occupational exposure to asbestos and (b) positive radiographic findings of asbestosis of the lungs (profusion of small opacities of at least 0/1) according to the ILO-U/C International Classification of Pneumoconiosis (10).

All the clinical examinations were performed by the same physician (the author). This reexamination included a standardized questionnaire on respiratory symptoms (13) and a medical history. It also included an appraisal of general health status, auscultation and a recording of crepitations in the chest. Crepitations were described as nonmusical explosive sounds during inspiration (7). The presence of finger clubbing was also estimated; it was recorded when the hyponychial angle was estimated to be $195^{\circ}$ or more by the method of Regan et al. (20).

Vital capacity (VC) and forced expiratory volume in $1 \mathrm{~s}\left(\mathrm{FEV}_{1.0}\right)$ were analyzed 
Table 2. Year of entry and age at entry into asbestos work.

\begin{tabular}{|c|c|c|c|c|c|c|c|c|c|c|}
\hline \multirow{2}{*}{ Occupation } & \multicolumn{5}{|c|}{ Year of entry } & \multicolumn{5}{|c|}{ Age at entry (years) } \\
\hline & $\leq 1929$ & $\frac{1930-}{1939}$ & $\begin{array}{r}1940- \\
1949\end{array}$ & $\begin{array}{c}1950- \\
1959\end{array}$ & $\geq 1960$ & $\leq 19$ & & $20-29$ & $30-39$ & $\geq 40$ \\
\hline $\begin{array}{l}\text { Insulation } \\
\text { workers } \\
\mathrm{N}:=55\end{array}$ & 5 & $(1923-1971)$ & 20 & 18 & 2 & 19 & mean & $\begin{array}{l}22 \\
24.9\end{array}$ & $\begin{array}{c}9 \\
(15-48)\end{array}$ & 5 \\
\hline $\begin{array}{l}\text { Asbestos } \\
\text { sprayers } \\
\mathrm{N}=8\end{array}$ & 0 & ${ }_{(1952-1965)}^{0}$ & 0 & 1 & 7 & 0 & mean & $\begin{array}{l}6 \\
25.6\end{array}$ & $\left(21{ }^{2}-35\right)$ & 0 \\
\hline $\begin{array}{l}\text { Asbestos } \\
\text { cement } \\
\text { product } \\
\text { factory } \\
\text { workers } \\
\mathrm{N}=\mathbf{3 2}\end{array}$ & 1 & $(1928-1966)$ & 15 & 6 & 2 & 1 & mean & $\begin{array}{l}11 \\
32.4\end{array}$ & $\stackrel{14}{(15-52)}$ & 6 \\
\hline $\begin{array}{l}\text { Asbestos } \\
\text { quarry } \\
\text { workers } \\
\mathrm{N}=29\end{array}$ & 0 & $(1931 \stackrel{6}{-} 1965)$ & 13 & 8 & 2 & 9 & mean & $\begin{array}{l}16 \\
22.8\end{array}$ & $\left(14^{4}-37\right)$ & $\mathbf{0}$ \\
\hline $\begin{array}{l}\text { Others } \\
\mathrm{N}=9\end{array}$ & 0 & $(1938-1968)$ & 1 & 4 & 3 & 0 & mean & $\begin{array}{l}3 \\
39.7\end{array}$ & $\stackrel{3}{(21-56)}$ & 3 \\
\hline $\begin{array}{l}\text { Total } \\
N=133\end{array}$ & 6 & $\stackrel{25}{(1923-1971)}$ & 49 & 37 & 16 & 29 & mean & $\begin{array}{l}58 \\
27.3\end{array}$ & $\begin{array}{c}32 \\
(14-56)\end{array}$ & 14 \\
\hline
\end{tabular}

Table 3. Length of asbestos exposure and smoking habits.

\begin{tabular}{|c|c|c|c|c|c|c|c|c|c|c|}
\hline \multirow{2}{*}{ Occupation } & \multicolumn{4}{|c|}{ Exposure (years) } & \multicolumn{2}{|c|}{$\begin{array}{c}\text { Non- } \\
\text { smokers }\end{array}$} & \multicolumn{2}{|c|}{ Exsmokers } & \multicolumn{2}{|c|}{ Smokers } \\
\hline & $\leq \mathbf{9}$ & $10-19$ & $20-29$ & $\geq 30$ & $\mathrm{~N}$ & $\%$ & $\mathrm{~N}$ & $\%$ & $\mathrm{~N}$ & $\%$ \\
\hline $\begin{array}{l}\text { Insulation } \\
\text { workers } \\
\mathrm{N}=\mathbf{5 5}\end{array}$ & 3 & $\begin{array}{c}14 \\
\text { mean }\end{array}$ & $6 \stackrel{22}{(5-47)}$ & 16 & 8 & 14.5 & 26 & 47.3 & 21 & 38.2 \\
\hline $\begin{array}{l}\text { Asbestos } \\
\text { sprayers } \\
\mathrm{N}=8\end{array}$ & 1 & $\begin{array}{c}6 \\
\text { mean } 1\end{array}$ & $8(6-24)$ & 0 & 2 & 25.0 & 3 & 37.5 & 3 & 37.5 \\
\hline $\begin{array}{l}\text { Asbestos } \\
\text { cement } \\
\text { product } \\
\text { factory } \\
\text { workers } \\
\mathrm{N}=32\end{array}$ & 6 & $\begin{array}{c}4 \\
\text { mean }\end{array}$ & $3(5-40)$ & 7 & 15 & 46.9 & 10 & 31.3 & 7 & 21.9 \\
\hline $\begin{array}{l}\text { Asbestos } \\
\text { quarry } \\
\text { workers } \\
\mathrm{N}=29\end{array}$ & 3 & $\begin{array}{c}8 \\
\text { mean }\end{array}$ & $21.8^{12}$ & 6 & 8 & 27.6 & 8 & 27.6 & 13 & 44.8 \\
\hline $\begin{array}{l}\text { Others } \\
\mathbf{N}:=9\end{array}$ & 4 & $\begin{array}{c}3 \\
\text { mean } 1\end{array}$ & $8 \quad \begin{array}{c}1 \\
(3-32)\end{array}$ & 1 & 1 & 11.1 & 6 & 66.7 & 2 & 22.2 \\
\hline $\begin{array}{l}\text { Total } \\
N=133\end{array}$ & 17 & $\begin{array}{c}35 \\
\text { mean } 2\end{array}$ & $1 \quad{ }^{51}(3-47)$ & 30 & 34 & 25.6 & 53 & 39.8 & 46 & 34.6 \\
\hline
\end{tabular}


from flow volume curves registered with a pneumotachograph (Medistor ${ }^{\circledR}$, U.S.A.) (3). $\mathrm{FEV}^{\%} \%$ was calculated as $\left(\mathrm{FEV}_{1.0} / \mathrm{VC}\right)$ $\times 100$. The single-breath transfer factor for carbon monoxide $\left(\mathrm{TL}_{\mathrm{c}_{0}}\right)$ was measured according to the usual procedure (19).

The radiographic reexamination included two full-size postero-anterior films and one lateral film. The radiographic technique has been described in detail by Zitting et al. (30). The chest films were all examined by the same three persons, i.e., two radiologists and a specialist in occupational medicine.

The patients were divided into three categories according to smoking habits: (a) smokers (persons who habitually carried cigarettes or pipe tobacco for their own use), (b) exsmokers (persons who had given up smoking at least a year earlier), and (c) nonsmokers (persons who did not and had never smoked regularly).
Copies of the death certificates of those who had died before 1977 were obtained from the Central Bureau of Statistics. The groups of death causes considered were: all causes, lung cancer, and all other types of cancer. Information on occupation and smoking habits was obtained either from earlier records of the Institute of Occupational Health or by inquiry from relatives of the deceased. The number of women in this series was so small that they were omitted from the analysis of mortality and survival. A series for analysis of mortality consisted of 56 dead male patients with asbestosis. Of these, 34 were smokers, 13 were ex- or nonsmokers, and the smoking habits of 9 men were unknown. The life expectancy study comprised 113 reexamined men, 56 dead men, and 5 men who did not attend the reexamination. The groups of exsmokers and nonsmokers were too small for separate analyses of survival, and therefore they were combined.

Table 4. Frequency of cough, persistent phlegm and breathlessness (13) according to smoking habits.

\begin{tabular}{|c|c|c|c|c|c|c|}
\hline \multirow{3}{*}{ Symptom } & \multicolumn{6}{|c|}{ Affirmative answers } \\
\hline & \multicolumn{2}{|c|}{$\begin{array}{c}\text { Nonsmokers } \\
(\mathrm{N}=34)\end{array}$} & \multicolumn{2}{|c|}{$\begin{array}{c}\text { Exsmokers } \\
(\mathrm{N}=53)\end{array}$} & \multicolumn{2}{|c|}{$\begin{array}{l}\text { Smokers } \\
(\mathrm{N}=46)\end{array}$} \\
\hline & $\mathrm{N}$ & $\%$ & $\mathrm{~N}$ & $\%$ & $\mathrm{~N}$ & $\%$ \\
\hline $\begin{array}{l}\text { Cough (on most days } \\
\text { for as much as } 3 \text { months } \\
\text { each year) }\end{array}$ & 23 & 58 & 38 & 72 & 44 & 96 \\
\hline $\begin{array}{l}\text { Persistent phlegm } \\
\text { (Production of phlegm at } \\
\text { least } 3 \text { months each year } \\
2 \text { years or more) }\end{array}$ & 19 & 56 & 36 & 68 & 40 & 87 \\
\hline $\begin{array}{l}\text { Breathlessness } \\
\text { Grade } 2 \text { or more } \\
\text { (shortness of breath when } \\
\text { hurrying on level ground } \\
\text { or walking up a slight hill) }\end{array}$ & 31 & 91 & 47 & 89 & 40 & 87 \\
\hline $\begin{array}{l}\text { Grade } 3 \text { or more } \\
\text { (short of breath when } \\
\text { walking with other people } \\
\text { of the same age on level } \\
\text { ground) }\end{array}$ & 25 & 74 & 41 & 77 & 34 & 74 \\
\hline $\begin{array}{l}\text { Grade } 4 \text { or more } \\
\text { (stopping for breath when } \\
\text { walking at own pace on } \\
\text { level ground) }\end{array}$ & 11 & 32 & 8 & 15 & 9 & 20 \\
\hline $\begin{array}{l}\text { Grade } 5 \\
\text { (short of breath when } \\
\text { putting on clothes or } \\
\text { moving out of doors) }\end{array}$ & 8 & 24 & 4 & 8 & 2 & 4 \\
\hline
\end{tabular}


Table 5. Clinical signs of the asbestosis patients according to the profusion of radiographic small pulmonary opacities.

\begin{tabular}{|c|c|c|c|c|}
\hline \multirow{2}{*}{ Groupa } & \multicolumn{2}{|c|}{$\begin{array}{l}\text { Crepitations in chest } \\
\text { (auscultation) }\end{array}$} & \multicolumn{2}{|c|}{ Finger clubbing } \\
\hline & $\mathrm{N}$ & $\%$ & $\mathrm{~N}$ & $\%$ \\
\hline RTG $0(N=65)$ & 25 & 38 & 14 & 22 \\
\hline RTG $1(N=48)$ & 33 & 69 & 18 & 38 \\
\hline RTG $2(\mathrm{~N}=20)$ & 19 & 95 & 11 & 55 \\
\hline All $(\mathrm{N}=133)$ & 77 & 58 & 43 & 32 \\
\hline
\end{tabular}

a Profusion categories: $0=0 / 1,1 / 0$ and $1 / 1 ; 1=1 / 2,2 / 1$ and $2 / 2 ; 2=$ $2 / 3$ or more.

The statistical analyses of the prevalence data were performed with the chisquare test or Student's t-test for independent samples. The mortality figures were based on patient-years. The patients were followed from the time of diagnosis to the end of 1976 or to death. The causeand age-specific as well as total mortality rates of the subjects were compared with the corresponding rates for men of the same ages in the general Finnish population in 1967 (29). The differences were tested by Mantel and Haenszel's chi-square test (12).

Survival rates were calculated by the life-table technique (1). The data were dichotomized according to smoking habits (smokers and exsmokers plus nonsmokers) and according to age at the time of diagnosis ( $<50$ or $\geq 50$ years). Survival rates were calculated separately for all four subgroups and also for the two smoking groups without regard for age at diagnosis.

\section{RESULTS}

\section{Symptoms}

Of the 133 patients examined, $95(71.4 \%)$ had persistent sputum defined as production of phlegm for two years or more during at least three months per year (table 4). Of the patients with persistent sputum,
$19(20.0 \%$ were nonsmokers and 36 $(37.9 \%)$ were exsmokers. Smokers had persistent sputum more often than nonsmokers $\left(\mathrm{p}<0.01 ; \chi^{2}=8.21\right)$ or exsmokers $\left(\mathrm{p}<0.05 ; \chi^{2}=3.96\right)$. Cough was more frequent among smokers than among non- or exsmokers $(p<0.01)$.

According to the patients' estimates cough and phlegm production began an average of 3.7 years before asbestosis was diagnosed.

Of the 133 patients, $118(88.7 \%)$ experienced some kind of breathlessness (table 4); they reported that dyspnea began an average of 3.5 years before asbestosis was diagnosed.

\section{Physical signs}

When the physical signs of asbestosis were checked, 77 patients $(57.9 \%$ ) had crepitations, which in 18 were heard toward the end of inspiration (table 5). Subjects with roengenographically advanced asbestosis had crepitations more often than those with slight $\left(p<0.001 ; \chi^{2}=13.70\right)$ or moderate changes $\left(\mathrm{p}<0.05 ; \chi^{2}=4.05\right)$. In addition those with moderate changes had crepitations more often than those with slight ones $\left(p<0.01 ; \chi^{2}=8.96\right)$.

As indicated in table 5, finger clubbing was present in $43(32.3 \%)$ patients. It was more frequently found in patients with advanced radiographic changes than in those with slight changes $\left(\mathrm{p}<0.01 ; \chi^{2}=\right.$ 6.65) (table 5). 
Comparison between symptoms and clinical findings

In patients with a history of breathlessness, $\mathrm{VC}$ and $\mathrm{FEV}_{1.0}$ were lower than in those without breathlessness (table 6), whereas $\mathrm{FEV} \%$ and $\mathrm{TL}_{\mathrm{L}_{00}}$ showed no statistically significant differences between these two groups of patients. The more severe the breathlessness, the lower the values for $\mathrm{VC}$ and $\mathrm{FEV}_{1.0}$ (table 6). Subjects with radiographically advanced asbestosis had dyspnea more often than those with slight roentgenographic changes (table 6). In this comparison the values for the different grades of dyspnea in the chi-square test were: $9.73(\mathrm{p}<0.01)$ for grade $3,5.02(\mathrm{p}<0.05)$ for grade 4 , and $16.72(\mathrm{p}<0.001)$ for grade 5. No statistically significant difference was found for

Table 6. Anamnestic breathlessness and its relation to lung function ( $\mathrm{VC}, \mathrm{FEC} 1.0$ and $\mathrm{T}_{\mathrm{L}_{\mathrm{CO}}}$ ) and radiographic findings.

\begin{tabular}{|c|c|c|c|c|c|c|c|c|c|c|c|c|c|c|c|}
\hline \multirow{3}{*}{$\begin{array}{l}\text { Grade of } \\
\text { breathless- } \\
\text { ness }^{a}\end{array}$} & \multicolumn{9}{|c|}{ Lung function } & \multicolumn{6}{|c|}{ Radiographic findingb } \\
\hline & \multicolumn{3}{|c|}{$\mathrm{VC}$} & \multicolumn{3}{|c|}{$\mathrm{FEV}_{1.0}$} & \multicolumn{3}{|c|}{$\mathrm{T}_{\mathrm{L}_{\mathrm{co}}}$} & \multicolumn{2}{|c|}{ RTG 0} & \multicolumn{2}{|c|}{ RTG 1} & \multicolumn{2}{|c|}{ RTG 2} \\
\hline & $\mathbf{N}$ & Mean & $\mathrm{SD}$ & $\mathrm{N}$ & Mean & $\mathrm{SD}$ & $\mathrm{N}$ & Mean & $\mathrm{SD}$ & $\mathbf{N}$ & $0 \%$ & $\mathrm{~N}$ & $\%$ & $\mathbf{N}$ & $\%$ \\
\hline 1 & 13 & 80 & 11 & 13 & 87 & 13 & 13 & 101 & 19 & 13 & 20 & 2 & 4 & 0 & \\
\hline 2 or more & 111 & 71 & 16 & 111 & 70 & 19 & 104 & 89 & 23 & 52 & 80 & 46 & 96 & 20 & 100 \\
\hline 3 or more & 92 & 68 & 15 & 92 & 67 & 18 & 85 & 86 & 24 & 39 & 60 & 39 & 81 & 20 & 100 \\
\hline 4 or more & 28 & 64 & 10 & 28 & 59 & 15 & 23 & 87 & 33 & 9 & 14 & 11 & 23 & 8 & 40 \\
\hline 5 & 14 & 65 & 11 & 14 & 57 & 15 & 11 & 90 & 36 & 2 & 3 & 7 & 15 & 8 & 40 \\
\hline
\end{tabular}

a Grade $1=$ no abnormal breathlessness; grade $2=$ able to work normally without breathlessness on level ground but breathless on hurrying or climbing a slight hill; grade $3=$ able to keep own (slower than average) pace on level ground; grade $4=$ forced to stop for breath when walking at own slow pace on level ground; grade $5=$ difficulties because of breathlessness while putting on clothes or walking out of doors.

b Profusion category: $0=0 / 1,1 / 0$ and $1 / 1 ; 1=1 / 2,2 / 1$ and $2 / 2 ; 2=2 / 3$ or more.

Table 7. The number of person-years of follow-up of male asbestosis subjects and observed and expected deaths.

\begin{tabular}{|c|c|c|c|c|c|c|c|}
\hline \multirow{3}{*}{$\begin{array}{l}\text { Age } \\
\text { group }\end{array}$} & \multirow{3}{*}{$\begin{array}{c}\text { Person- } \\
\text { years }\end{array}$} & \multicolumn{6}{|c|}{ Cause of deatha } \\
\hline & & \multicolumn{2}{|c|}{ All causes } & \multicolumn{2}{|c|}{ Lung cancer } & \multicolumn{2}{|c|}{ Other malignomas } \\
\hline & & Observed & Expected & Observed & Expected & Observed & Expected \\
\hline $25-29$ & 3 & 0 & 0.0 & 0 & 0.0 & 0 & 0.0 \\
\hline $30-34$ & 14 & 0 & 0.0 & 0 & 0.0 & 0 & 0.0 \\
\hline $35-39$ & 55 & 0 & 0.2 & 0 & 0.0 & 0 & 0.0 \\
\hline $40-44$ & 124 & 0 & 0.7 & 0 & 0.0 & 0 & 0.1 \\
\hline $45-49$ & 206 & 6 & 1.8 & 1 & 0.1 & 0 & 0.2 \\
\hline $50-54$ & 211 & 6 & 2.8 & 3 & 0.2 & 0 & 0.4 \\
\hline $55-59$ & 215 & $14^{* * *}$ & 4.7 & $7 * * *$ & 0.5 & 1 & 0.5 \\
\hline $60-64$ & 208 & $15^{* *}$ & 6.5 & $6^{* * *}$ & 0.7 & 2 & 0.9 \\
\hline $65-69$ & 110 & 11 & 5.3 & 1 & 0.5 & 0 & 0.7 \\
\hline $70-74$ & 19 & 3 & 1.3 & 1 & 0.1 & 0 & 0.2 \\
\hline $75-79$ & 1 & 1 & 0.1 & 0 & 0.0 & 0 & 0.0 \\
\hline \multirow[t]{2}{*}{ All } & 1,168 & $56^{* * *}$ & 23.4 & $19 * * *$ & 2.0 & 3 & 3.0 \\
\hline & & \multicolumn{2}{|c|}{$\left(\chi^{2}=44.0\right)$} & \multicolumn{2}{|c|}{$\left(\chi^{2}=128.1\right)$} & \multicolumn{2}{|c|}{$\left(\chi^{2}=0\right)$} \\
\hline
\end{tabular}

a Significance of excess mortality based on the Poisson distribution or the chi-square test. $* * \mathrm{p}<0.01 ; * * * \mathrm{p}<0.001$. 
Table 8. Mean survival times of patients with asbestosis.

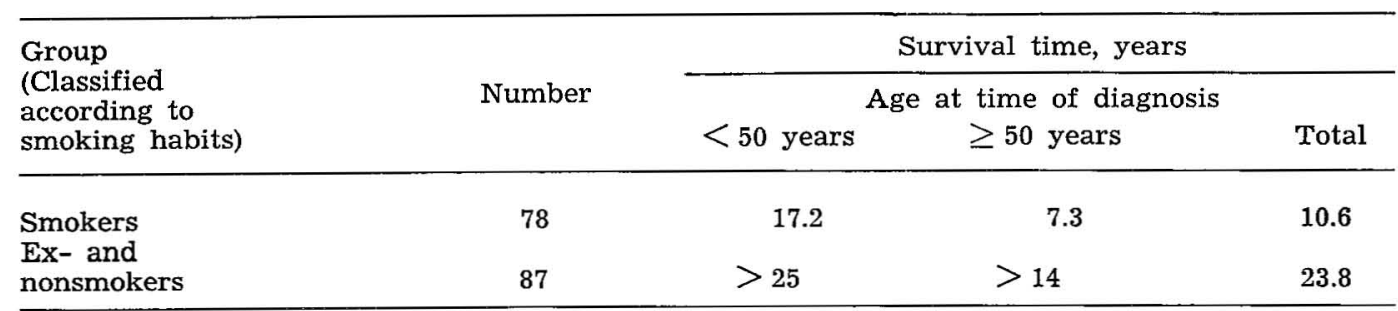

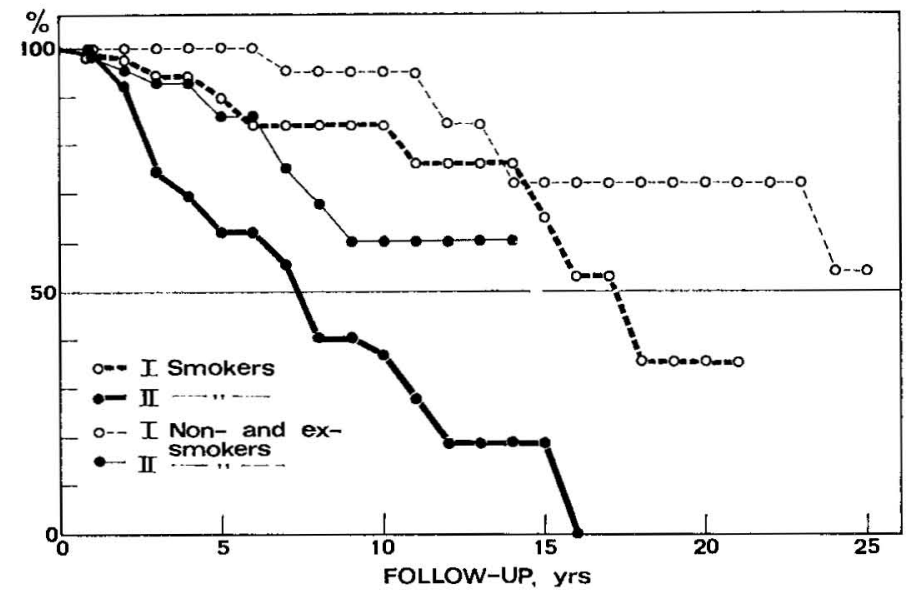

Fig. 1. Survival analysis of male asbestosis patients classified according to smoking habits and age at the time of diagnosis $(\mathrm{I}=<50$ years of age; II $\geq 50$ years of age). the weights of the patients with different grades of dyspnea and radiographic findings. Neither was persistent sputum statistically significantly related to the profusion of small pulmonary opacities or lung function test results.

\section{Causes of death}

The underlying cause of death of the 62 patients (men and women) who had died before 1977 were as follows: (a) asbestosis $26(41.9 \%$ ), (b) lung cancer $20(32.2 \%$, (c) other malignomas $4(6.5 \%)$, and (d) other causes $12(19.4 \%)$. In 12 of the cases with asbestosis as the underlying cause, cor pulmonale was listed as the immediate cause of death. Four of the six women had died of asbestosis, one of lung cancer and one of cancer of the esophagus. The average age of all 62 persons at death was 60.4 years (range 45-76 years).

Among the patients who died of lung cancer, the average period from the beginning of asbestos exposure to the di- agnosis of asbestosis was 22.4 years (range $2-37$ years). The average period from the date of diagnosis to death was 8.5 years (range $0-23$ years). The average age at death was 58.3 years. Only one subject who died of lung cancer (histologically anaplastic) was a nonsmoker. Lung cancer was peripheral in 17 and central in 3 cases. Peripheral cancers were located in the upper lobe in 11 cases and in the lower lobe in 6 cases. Of the 12 cases that were examined histologically, the carcinoma was found to be epidermoid in 4, anaplastic (microcellular) in 4 and adenomatous in 4 cases.

\section{Mortality}

The total number of deaths among the male patients between 1964 and 1976 was 56 . As the expected number estimated from the death rates of the Finnish male population was only 23.4 , there were 32 more deaths than expected. For deaths from lung cancer, the ratio was even more un- 
favorable; 19 deaths were observed and 2.1 expected. These differences are statistically highly significant. For both total deaths and deaths from lung cancer the excess mortality occurred in the age group of 55-64 years. No excess mortality was found for other malignomas (table 7).

\section{Survival rates}

The mean survival times $\left(\mathrm{L}_{\tilde{5} 0}\right.$, years) are shown in table 8 . The respective curves are presented in fig. 1 . As the two smoking-habit groups had practically the same age distribution, the age categories could be combined without invalidating the comparison of the two groups. In both age groups the estimated survival time for smokers was shorter than for ex- and nonsmokers. The differences were statistically significant.

\section{DISCUSSION}

According to Parkes (18) there is no evidence to suggest that chronic bronchitis is causally related to asbestosis. However, it has also been suggested that cough, either productive or nonproductive, occurs with greater frequency in asbestos-exposed workers than in nonexposed persons, and often it cannot be attributed to differences in smoking habits (2). Smoking is known to be the chief etiological factor for chronic bronchitis however, and its effect overshadows the influence of other weaker, e.g., occupational, agents. In the present study 19 of the 95 patients with persistent sputum were nonsmokers; hence also my results suggest that exposure to asbestos might cause irritation of respiratory airways.

The onset of breathlessness is often insidious in asbestosis, and it occurs at first only during physical effort (2). In this study I found no dyspnea among 15 of the patients, of which 13 revealed only slight changes in their radiographs. Among the patients, the degree of breathlessness generally showed a relationship with the ra- diographic severity of asbestosis and with a decrease in $\mathrm{VC}$ and $\mathrm{FEV}_{1.0}$ (table 6). Contrary opinions have also been presented, however, concerning the relationship between breathlessness and the severity of radiographic asbestosis (18).

My results suggest that breathlessness is the most important symptom of asbestosis because, generally, the more severe the breathlessness, recorded on a standardized questionnaire (13), the greater the decrease in $\mathrm{VC}$ and $\mathrm{FEV}_{1.0}$ and the more diffuse the lung fibrosis in the radiographs (30).

In asbestosis patients lung cancer is usually situated peripherally in the lower lobe of the lung $(9,28)$, whereas peripheral lung cancers in general seem to be situated in the upper lobe of the lung (25). In the present study 11 of the peripheral lung cancers were in the upper and 6 in the lower lobe of the lung. Thus the location of lung cancer in these patients was unexpected.

Although several authors have stressed an increased occurrence of adenocarcinoma $(8,9,24,28)$, other histological types of lung cancer have also been found in asbestosis patients (11). However, in the present study the distribution of various histological types of lung cancer corroborates that of the Finnish population in general.

Of the asbestos fibers, crocidolite probably carries the greatest risk for lung cancer (6). The longer and narrower the asbestos fibers are, the more dangerous they are (5). In the present study nine of the lung cancer patients were insulators, six were asbestos quarry workers, four worked in a factory manufacturing asbestos cement products, and one was a carpenter who had been indirectly exposed to asbestos dust during construction work. Their exposure to asbestos dust varied greatly both in quality and quantity. The asbestos quarry workers had been exposed to anthophyllite. In the other occupations the exposure was mixed, consisting chiefly of chrysotile with smaller amounts of anthophyllite, crocidolite and amosite. Because of the small number of cases and the mixed exposure, it is difficult to evaluate the risk that should be attributed to different types of fibers with respect to lung cancer.

Saracci (21) has suggested that the synergism between exposure to asbestos and 
smoking in producing human lung cancer is probably multiplicative rather than additive. Among the carcinogenic factors of asbestosis and asbestos-related disorders, tobacco plays an important role (22). Of the patients with lung cancer in this study, one was a nonsmoker and the smoking habits of four were unknown. The data of the present study were scanty for the evaluation of risk rate ratio for lung cancer between smoking and nonsmoking patients, but the risk of death from lung cancer was increased for the asbestosis patients, the risk rate ratio being 9.0. Among the same subjects the risk rate ratio for overall mortality was 2.4. Both of these figures corroborate the results of previous studies $(4,14,15,16,17,22,23)$.

Tobacco smoking seems to be an important factor in the short life expectancy of men with asbestosis (fig. 1). Calculations for survival rates were performed for 165 patients, and, even if all nine of the patients whose smoking habits were unknown had been nonsmokers, the shorter life expectancy for smokers would remain significant.

\section{ACKNOWLEDGMENTS}

My thanks are due to Sisko Asp, M.Pol. Sc., for her expert help in the statistical treatment of the data, especially concerning observed and expected deaths and life expectancy.

\section{REFERENCES}

1. ARMITAGE, P. Statistical methods in medical research. Blackwell Scientific Publications, Oxford and Edinburgh 1971, pp. $410-414$

2. BECKLAKE, M. R. Asbestos-related diseases of the lung and other organs: Their epidemiology and implications for clinical practice. Am. rev. respir. dis. 114 (1976) $187-227$.
3. BERGLUND, E., BIRATH, G., BJURE, J., GRIMBY, G., KJELLMER, J., SANDQVIST, L. and SÖDERHOLIM, B. Spirometric studies in normal subjects: I. Forced expirograms in subjects between 7 and 70 years of age. Acta. med. scand. 173 (1963) 185.

4. BUCHANAN, W. D. Asbestosis and primary intrathoracic neoplasms. Ann. n.y. acad. sci. 132 (1965) 508-518.

5. CARTER, R. L. and ROE, F. J. C. Chemical carcinogens in industry. $J$. soc. occup. med. 25 (1975): 3, 86-94.

6. ENTERLINE, P. E. and HENDERSON, V. Type of asbestos and respiratory cancer in the asbestos industry. Arch. environ. health 27 (1973) 312-317.

7. HARRIS, P. G. Clinical signs. In: Biological effects of asbestos. International Agency for Research on Cancer, Lyon 1973, pp. $19-24$.

8. HOURIHANE, D. O'B. and MC CAUGHEY, W. T. E. Pathological aspects of asbestosis. Postgrad. med. 42 (1966) 613622.

9. HUEPNER, W. C. (ed.). Occupational and environmental cancer of the respiratory tract: Recent results in cancer research (vol. 3). Springer, Berlin 1966. $43 \mathrm{p}$.

10. INTERNATIONAL LABOUR OFFICE. ILO-U/C international classification of pneumoconioses (Occupational safety and health series 22 (rev.)). Geneva 1972. 32 p.

11. KANNERSTEIN, M. and CHURG, J. Pathology of carcinoma of the lung associated with asbestos exposure. Cancer 30 (1972) $14-21$.

12. MANTEL, N. and HAENSZEL, W. Statistical aspects of the analysis of data from retrospective studies of disease. J. natl. cancer inst. 22 (1959) 719

13. MEDICAL RESEARCH COUNCIL. Standardized questionnaires on respiratory symptoms. Br. med. j. 2 (1960) 1665.

14. MEREWETHER, E. R. A. Annual reports chief inspector of factories, 1947. Her Majesty's Stationary Office, London 1949.

15. MEURMAN, L., KIVILUOTO, R. and HAKAMA, M. Mortality and morbidity among the working population of anthophyllite asbestos miners in Finland. Br. $j$. ind. med. 31 (1974) 105-112.

16. NEWHOUSE, M. L. A study of the mortality of workers in an asbestos factory. Br. j. ind. med. 26 (1969) 294-301.

17. NURMINEN, M. A study of the mortality of workers in an anthophyllite asbestos factory in Finland. Work-environ.-health 9 (1972) 112-118.

18. PARKES, W. R. Asbestos-related disorders. Br. j. dis. chest 67 (1973) 261-300.

19. PYÖRĂLĂ, K., HEINONEN, A. O. and KARVONEN, M. J. Pulmonary function in former endurance athletes. Acta med. scand. 183 (1968) 263-273.

20. REGAN, G. M., TAGG, B. and THOMSON, M. L. Subjective assessment and objective measurement of finger clubbing. Lancet 1 (1967) $530-532$. 
21. SARACCI, R. Asbestos and lung cancer: An analysis of the epidemiological evidence on the asbestos-smoking interaction. Int. $j$. cancer 20 (1977) 323-331.

22. SELIKOFF, I. J. Asbestos disease in the United States 1918-1975. Mal. resp. 1 (1976): 4, 7-24.

23. SELIKOFF, I. J., HAMMOND, E. C. and CHURG, J. Asbestos exposure, smoking and neoplasia. J. am. med. assoc. 204 (1968) 106-112.

24. SPENCER, H. (ed.). Pathology of the lung (2nd ed.). Pergamon Press, Oxford 1968. $788 \mathrm{p}$.

25. TALA, E. Carcinoma of the lung: A retrospective study with special reference to prediagnostic period and radiographic signs. Acta radiol. (1967): suppl. 268.

Received for publication: 14 September 1978
26. TURNER-WARWICK, M. A perspective view on widespread pulmonary fibrosis. Br. med. j. 2 (1974) 371-376.

27. WEGELIUS, C. Changes in the lungs in 126 cases of asbestosis observed in Finland. Acta radiol. 23 (1947) 139-152.

28. WHITEWELL, F., NEWHOUSE, M. L. and BENNET, D. R. A study of the histological cell types of lung cancer in workers suffering from asbestosis in the United Kingdom. Br. j. ind. med. 31 (1974) 298-303.

29. WORLD HEALTH ORGANIZATION. World health statistics annual 1967: Vital statistics and causes of death. Geneva 1970.

30. ZITTING, A., HUUSKONEN, M. S., ALANKO, K. and MATTSSON, T. Radiographic and physiological findings in patients with asbestosis. Scand. j. work environ. \& health 4 (1978) 275-283. 